НАЦІОНАЛЬНА БЕЗПЕКА ТА ПРАВА ЛЮДИНИ

UDC $347.78(477+569.5)$

DOI: https://doi.org/10.32631/pb.2020.3.02

BASHAR MALKAWI,

Doctor of Juridical Science

(Societies Juridical Doctor, S.J.D),

College of Law, University of Sharjah;

SERHII YEVHENOVYCH ABLAMSKYI,

Candidate (Ph.D.) of Juridical Sciences, Docent,

Kharkiv National University of Internal Affairs;

https://orcid.org/0000-0003-4716-3985

\title{
COPYRIGHT NORMS, COPYRIGHT INFRINGEMENTS AND REMEDIES IN UKRAINE AND JORDAN: WHAT INTERESTING COMPLEXITIES TELL OF TWO JURISDICTIONS?
}

\begin{abstract}
Issue of copyright protection has been a great initiative gaining laudable ground in the world of intellectual property law, as it seeks to protect and safeguard the ideas of the author for it not to be violated and infringed upon by another without the author's consent or authorization. In ensuring author's right, a plethora of international, regional, and even national legal dispositions has been put in place for guaranteeing that works of author's should be protected against infringement. In response to these commitments, the states of Ukraine and Jordan have played a credible role by adhering and been signatories to these legal dispositions to endure copyright protection. Even though with all these protection being put into place by the said countries, there is still an aspect of infringement and violations, which has frustrated the rational of the law as it is aimed at ensuring copyright protection. The objective of this article is to study the implications that copyright infringement poses on the fundamental rights of an author's work. It is clear that aspect of copyright infringement affects the rights possessed by author in issues related to copyright protection in Ukraine and Jordan. While answering the fundamental question as to the aspect of copyright infringement in both countries, a comparative study was deemed necessary in order to study whether both countries experience same difficulties as a result of copyright infringement. It was realized from the findings that issues of infringement, even though with the credible laws and institutions put in place by both countries, has been a common problem. Therefore, it has been noted that a research of this magnitude was deemed necessary in ensuring that copyright of author's should be guaranteed and protected.
\end{abstract}

Key words: copyright, author, legal norms, copyright infringement.

Original article

\section{Introduction}

The problem of intellectual property protection is coming to the fore in the world now, even despite the significant efforts of the international community on this issue. The main international conventions that protect copyright works are the Berne Convention and the TRIPs Agreement. Countries acceding to the WTO must comply with the TRIPs Agreement as well as the Berne Convention ${ }^{1}$. However, the TRIPs Agreement does not

1 Article 9.1 of TRIPs requires members to comply with articles 1 through 21, with the exception of article 6bis, of the 1971 Paris Act of the Berne recognize moral rights of copyrighted works ${ }^{2}$. Moreover, the TRIPs Agreement addresses aspects of copyright related to new technologies such as computer programs.

In addition, the Universal Copyright Convention of 1952 (Geneva), the International Convention for the Protection of Performers, Producers

Convention and the Appendix thereto (that is, the substantive provisions of that Convention). Jordan joined the Berne Convention in 1999.

2 In fact, the TRIPS Agreement explicitly excludes article 6bis of the Berne Convention on moral rights from its application. See TRIPS, art. 9.1. 
of Phonograms and Broadcasting Organizations of 1961 (Rome Convention), the Convention establishing the World Intellectual Property Organization of 19671, the Convention for the Protection of Producers of Phonograms Against Unauthorized Duplication of Their Phonograms of 1971 (Geneva), the Agreement on Cooperation in the Field of Protection of Copyright and Related Rights of 1993, etc. were an important international legal basis for the protection of copyright and related rights.

For the legal field of Ukraine, in particular with regard to copyright protection, the importance of these international documents is due to the fact that in September 2014 Ukraine ratified the Association Agreement between Ukraine, of the one part, and the European Union, the European Atomic Energy Community and their Member States, of the other part ${ }^{2}$. Thus, one of the objectives set out in Chapter 9 of this agreement is to achieve an appropriate and effective level of protection and defense of intellectual property rights. Thus, since then, the Ukrainian Government is committed to approximating national legislation to that of the European Union in the field of intellectual property. In this regard, Chapter 9 "Intellectual Property" of Section IV of the Association Agreement, which contains the main provisions of the relevant EU directives and regulations on various aspects of intellectual property protection, including copyright and related rights, is essential. Therefore, the relevant European regulations have already been practically integrated into the legislative field of Ukraine. It should be noted that one of the countries mentioned in the Preamble of the Association Agreement is Jordan, in this regard the issue of comparative analysis of the legislation of Ukraine and Jordan in the field of copyright protection is quite relevant. Moreover, taking into account the differences in the legislation of the two countries, this study is quite interesting.

A. A Complex and Complementary Nature of Copyright Subject Matter

Jordan's current copyright law can be found, primarily, in the Copyright Law of 2001. Article 4 provides that copyright generally vests in the cre-

${ }^{1}$ Convention establishing the World Intellectual Property Organization (signed in Stockholm on July 14, 1967 and amended on October 2,1979).

2 Association Agreement between Ukraine, of the one part, and the European Union, the European Atomic Energy Community and their Member States, of the other part: International document of 27.06.2014. https://zakon.rada.gov.ua/laws/show/ 984_011 [Accessed 16 August]. ator or author of the work. However, articles 5 and 6 specify further conditions under which for example an employer may be regarded as the copyright owner.

The Law of Ukraine "Copyright and Related Rights was adopted on December 23, 1993, but the Law of July 11, 2001 amended it accordingly. Today, this law protects the and proprietary rights of authors and their successors related to the creation and use of works of science, literature and art - copyright, and the rights of performers, producers of phonograms and videograms and broadcasting organizations - related rights.

The domain or subject matter of copyright protection is literary, scientific, and artistic works ${ }^{3}$. These conventional works include written materials, music, works of fine arts such as paintings and photography, and technology based works such as computer programs. Thus, Jordan's Copyright Law of 2001 includes software within the ambit of copyright protection. As a result, foreign software developers would rely on explicit provisions for protection before licensing their best technologies. Article 3.d of the Copyright Law also mandates protection for encyclopedias, an area not previously covered, which by reason of selection or arrangement of contents constitute intellectual creations as such. The list in Copyright Law of 2001 is not intended to be inclusive. It is only meant to illustrate the nature of literary, scientific, and artistic works.

As for the objects of copyright under the current Law of Ukraine "Copyright and Related Rights", their list is given in article 8 of this Law. In this context, it should be born in mind that the protection provided applies only to the form of expression of the work and does not apply to any ideas, theories, principles, methods, procedures, processes, systems, methods, concepts, discoveries, even if they are expressed, described, explained, illustrated in the work. Instead, this law does not resolve the problematic issues regarding copyright and related rights protection concerning the use of modern technology, such as distribution of copies of works, phonograms, videograms in electronic form, Internet piracy, etc.

Copyright protects the expression of thoughts but not the ideas themselves ${ }^{4}$. For example, if somebody writes a book about Jordan's accession to the WTO, his/her expressions are protected, but not the idea or the topic of Jordan's accession to the WTO since anybody could write

3 Provisional Copyright Law No. 52 of 2001, art. 3.a, Official Gazette No. 4508 (Oct. 1, 2001). This is in compliance with article 2 of the Berne Convention.

4 TRIPS, art. 9.2. 
about Jordan's accession to the WTO. Under Jordan's Copyright Law, innovative expressions are protected $^{1}$. Copyright Law of 2001 provides that a work is made when it is reduced to writing or other material form. There are no other formalities for copyright to be acquired or as precondition of filing a lawsuit. For example, there are no requirements for registration of the work, recordation, or copyright notice. However, the inquiry that must be pursued by court decisions and commentators in Jordan is whether Copyright Law should protect a work (for example a statistical form) as whole, including original expressions, non-original expressions, and facts, or it should protect the original expressive elements of a work so as to identify them with as much certainty as possible. In other words, the question is whether to adopt the "work as a whole" approach or the "element by element" approach.

The Copyright Law of 2001 applies to published or unpublished works of Jordanians and foreigners. It requires Jordan to extend its copyright law protection to nationals of other countries $^{2}$. Thus, Copyright Law of 2001 recognizes the personal status of the author as a Jordanian citizen or national (including resident) of other country as a connecting factor to secure protection in Jordan.

In accordance with the legislation of Ukraine, all works specified in part 1 of article 8 of the Law of Ukraine "Copyright and Related Rights", both

1 Provisional Copyright Law No. 52 of 2001, supra note 5, art. 3.a \&b. Article 38 of the Copyright Law addresses filing of best edition of a published work with the Filing Center in the National Library Department. However, it seems that the Law established a policy of flexibility by stating in article 45 that non-filing cannot be considered a violation of the Law. As such, filing is considered a procedural step and not condition to secure copyright protection. Depositing a published work in the Filing Center would help the flow of materials to the Department, evidentiary use in the judicial system, and serve the public interest in an open and comprehensive registry.

${ }^{2}$ However, under article 53.b of the Copyright Law of 2001, copyright protection would apply based on reciprocity, not national treatment, for non-members of an international copyright agreement (the Berne Convention). In any case, Jordan will have to apply its copyright law to works of all TRIPs members even if they are not parties to the Berne Convention by virtue of the principles of national treatment and MFN incorporated in TRIPs. On this basis, one can argue that Jordan is obliged to protect works of TRIPs parties who may or may not be Berne parties. published and unpublished, both completed and incomplete, regardless of their purpose, genre, volume, goals (education, information, advertising, propaganda, entertainment, etc.) should be protected. In addition, according to the legislation of Ukraine, foreigners and stateless persons, in accordance with international agreements or on the basis of the principle of reciprocity, have the same rights as persons of Ukraine provided by this Law.

There are certain works that are excluded from protection under the Copyright Law of 2001. For example, legislations, regulations, judicial decisions, and other official texts of a legislative, administrative or legal nature are not protected. However, these official texts are protected to the extent they involve innovation in their arrangement. For example, if a person compiles Jordan's trade laws, bilateral trade agreements, and WTO Agreements in a supplementary book by providing indices, certain selections for publication, and brief commentaries at the end of each article, then his/her compilation could be copyrighted. Also, there is no copyright in news information per se. In Jordan, there is no specific exclusion of protection for political or legal speeches if they are, of course, literary works reduced to writing or other material form.

According to Article 10 of the Law of Ukraine "Copyright and Related Rights" the following items shall not be objects of copyright: a) daily news or current events information that are regular press information; b) works of folk art (folklore); c) official documents of a political, legislative, or administrative nature (laws, decrees, resolutions, court awards, State standards, etc.) issued by government authorities within their powers, and official translations thereof; d) State symbols of Ukraine, government awards; symbols and signs of government authorities, the Armed Forces of Ukraine and other military formations; symbols of territorial communities; symbols and signs of enterprises, institutions and organizations; e) bank notes; f) transportation schedules, TV and radio broadcast schedules and telephone directories and other similar databases that do not meet the originality criteria and to which the sui-generis right (a peculiar, special right) is applicable.

The drafts of the official symbols and signs specified in clauses d) and e) of this Article, before they are officially approved, shall be considered as works and protected pursuant to this Law.

Folklore, which is usually conveyed through the intervention of performers whereby those folkloric expressions are communicated to the public, is not protected under Jordan's Copyright Law of 2001. On the contrary, it falls within public 
domain 1 . In other words, it is the intellectual property of nobody. Examples of folklore include such artistic expressions as a tribal dance. However, the minister of culture will exercise his authority as the owner of folklore by providing protection against distortion or misrepresentation ${ }^{2}$ In other words, the minister of culture will exercise his authority over these works as moral rights. Thus, protection of the vast, ancient and invaluable cultural expression is afforded, when there is distortion or misrepresentation, by all means without limitation in time. The provision of Jordan's Copyright Law does not speak of the minister of culture exercising economic rights over these works, though one might argue that he can. This means that any person intends to exploit works of folklore might want to ask the permission from the minister of culture.

It should be noted that during all the years of independence, Ukraine did not have a legal mechanism that would provide authors, composers, performers and other creators with a decent reward for their creative intellectual activity. Relevant guarantees provided by the Constitution in 1996, are still, unfortunately, only declarations. The constitution in Jordan does not mention anything about intellectual property though it protects property in general. In other words, there are no specific provisions in the Jordanian constitution that would address copyright or other forms of intellectual property.

B. The Place of Exclusive Rights in both Jurisdictions

There are two types of rights under the copyright law. These are economic rights, which allow the author of a work to derive financial reward (through licensing) from the use of his work by others, and moral rights, which allow the author to take certain actions to preserve the personal linkage between him and the work (arts. 8, 9 Copyright Law of 2001). Leaving aside moral rights, the Copyright Law of 2001 sets out a number of exclusive rights, which are to be granted to authors.

According to the legislation of Ukraine, copyright consists of non-proprietary (personal) and proprietary rights of the author. Non-proprietary rights are inalienable, i.e. any work has an author who will always be the author - from the moment of creation of this work and for the entire period

1 Jordan's Copyright Law of 2001 provides a "catch-all" phrase. It states that all works that fall into public domain are not copyright protected.

2 Because works of folklore do not have a single identifiable author capable of exploiting these works, the Copyright Law of 2001 gives ownership of such works to the minister of culture. of its existence. Proprietary rights can be transferred to others as a gift, by agreement or for a fee. The person who has proprietary rights to the work is its right holder. He has the right to use the work at his own discretion (sell copies, translate, publish, screen, etc.).

Copyright (proprietary) or related rights may arise when: 1) the person has independently created a work of intellectual property; 2) the person inherited the copyright to the work, or received the copyright by inheritance; 3 ) copyright or related rights are transferred in accordance with the terms of the copyright agreement. Any registration of rights to a specific intellectual property product is not mandatory, the creation of copyright does not require registration of the work or any other special processing, as well as the implementation of any other formalities.

The right of the author of a copyrighted work to exclude others from making copies of his work is the basic right under copyright. Without going into the details, economic rights, which involve commercial exploitation of protected works, include the right of publishing when a publisher is authorized to make copies of a protected work. Other economic rights include the right of broadcasting, the right to authorize distribution, the right of reproduction, the right of commercial rental, and the right of public recitation ${ }^{3}$.

Copyright Law of 2001 also protects acts of translation and adaptation. Translation means the expression of a work in a language other than that of the original version. Adaptation means the modification or conversion of a work to create another work such as converting a novel into a motion picture. Since translation and adaptation are works protected by the Copyright Law of 2001 for any reproduction or publication of a translated or adapted copy, an authorization must be obtained from both the owner of the copyright in the original pre-existing work and the adaptator or translator.

Similar provisions are enshrined in article 20 of the Law of Ukraine "Copyright and Related Rights". In particular, translators and authors of other derivative works shall hold a copyright with

3 The right of rental is not available under the Berne Convention. However, it is made available under article 11 of TRIPs. The right of rental is important because technological advances such as digital audio tape made it very easy to copy computerbased programs, films, or sound recordings by customers of rental stores. Therefore, the right to control commercial rental practices is necessary in order to safeguard the copyright owner's sales market and royalties. 
respect to their translation, adaptation, arrangement or other re-making. The translator and (or) the authors of other derivative works shall hold the copyright with respect to their work provided that they observe the rights of the author whose work has been translated, adapted, arranged or otherwise remade. The copyright of translators and (or) authors of other derivative works shall not hinder other persons' translation and remaking of the same works.

Article 23 of the Copyright Law of 2001 is concerned with neighboring or related rights ${ }^{1}$. For example, a singer that performs a composer's work to the public is considered a holder of a neighboring right. Copyright Law of 2001 confers rights on performers, broadcasting organizations, and producers of phonograms ${ }^{2}$. The right of performers is recognized because their creativity gives spirit to the body of poems for example. The same recognition also applies to broadcasting organizations because of their contribution of making works available to the public. Also, producers of sound recordings are recognized because their creativity in contributing to the work. In principle, the rights of holders of these related rights are similar to the rights of holders of other copyrighted works.

According to article 13 of the Law of Ukraine "Copyright and Related Rights" co-authors are persons whose joint creative effort resulted in a work. Copyright with respect to a work created in co-authorship shall be vested with all co-authors irrespective of whether the work is a single inseparable item or is composed of parts each having independent significance. If a work created in co-authorship is a single inseparable item, neither co-author shall, without sufficient grounds, deny permission to the other authors to publish or otherwise use or alter the work.

Section III of the Law of Ukraine "Copyright and Related Rights" is devoted to the protection of related rights. Objects of related rights, irrespective of destination, contents, evaluation, or method and form of expression, shall be: a) performances of literary, dramatic, musical, musical drama, choreographic, folklore and other works; b) phonograms, videograms; c) broadcast organization broadcasts (programs). Related rights holders shall be: a) performers of works, their heirs and persons to whom related proprietary rights to performances have been assigned on

1 Neighboring rights named as such because they build upon and relate to already protected copyrighted works.

2 Provisional Copyright Law No. 52 of 2001, supra note 5 , art. 23. a, b \& c. legal grounds; b) manufacturers of phonograms, their heirs (successors) and persons to whom related proprietary rights to phonograms have been assigned on legal grounds; c) manufacturers of videograms, their heirs (successors) and persons to whom related proprietary rights to videograms have been assigned on legal grounds; d) broadcast organizations and their successors.

Performers are provided the rights to prevent fixation of unfixed performance, broadcasting and communication to the public of their live performances without their consent, and the right to prevent reproduction of fixations of their performances ${ }^{3}$. Essentially, this means that performers could prevent the making of a sound recording or bootleg recording of the live performance. In addition, Copyright Law protects producers of phonograms and broadcasting organizations. A note worth stating here is that Jordan's Copyright Law extends commercial rental rights to include works reproduced in sound recording.

\section{Moral Rights}

Article 8 of Copyright Law of 2001 recognizes moral rights ${ }^{4}$. The basis for these rights is the personal linkage between the work and its author. As such, an author has the right to claim/ disclaim a work as his own (authorship or paternity) and to safeguard the work from distortion, mutilation, and other amendments which would be prejudicial to his reputation or honor (integrity). Based on this, the author in Jordan can prevent others from passing off his work as theirs. Additionally, the author may be able to block usage of a work, such as in parody, which he feels will prejudice his honor.

According to the legislation of Ukraine, moral rights are enshrined in the form of personal nonproprietary rights. Thus, in accordance with article 14 of the Law of Ukraine "On Copyright and Related Rights" the author has the following personal non-property rights: 1 ) to require recognition of his authorship by properly indicating the

${ }^{3}$ Art. 23.a. Copyright Law of 2001 does not define the term "fixation" and whether it covers audiovisual fixation or aural fixation.

${ }^{4}$ The often-used translation for the word "copyright" into Arabic in Jordan is the author's right. This use of the term "author's right" could be attributed to putting more emphasis on moral rights (personality link), as supposed to economic rights such as reproduction, of the author. Hence, it is author's right. Alternatively, the term "author's right" could have the same meaning as the term "copyright". Article 6bis of Berne Convention requires members to recognize the author's moral right of integrity and the right to claim authorship. 
author's name on a work and its specimens and during any public use of the work, if practicable; 2) to prohibit the mentioning of his name during a public use of a work, if the author wishes to remain anonymous; 3 ) to choose a pseudonym, to indicate and require indication of a pseudonym instead of the author's real name on a work and its specimens and during any public use thereof; 4) to require preservation of the integrity of a work, and to counteract any twisting, distortion or other alteration of a work, or any other encroachment thereon that may prejudice the author's honor and reputation.

Moral rights of authorship and integrity are distinct from the bundle of economic or exploitation rights that are usually associated with copyright. Economic rights of the type mentioned earlier can be transferred or assigned to others in return of royalties. However, the second type of rights, moral rights, cannot be transferred. They always remain with the original author of the copyrighted work. In other words, they are inalienable and perpetual.

\section{Exceptions}

There are certain exceptions or limitations to the general rule of prior authorization of the owner of a work. Some of these exceptions fall under three-step test of article 13 of the TRIPs Agreement. Other limitations fall under article 9.1 of the TRIPs Agreement that includes the appendix of the Berne Convention of 1971. The former limitations could be labeled as fair uses while the latter are non-voluntary licenses. Both of these exceptions are covered under the current version of Jordan's Copyright Law of 2001'. The difference between fair use and non-voluntary license is that under free use exploitation of a copyrighted work is carried out without authorization and an undertaking to remunerate the owner of copyrighted work for the use. On other hand, exploitation under the non-voluntary license is carried out without authorization but with the obligation to compensate the owner of rights.

For example, under the fair dealing defense of Copyright Law of 2001, individuals are allowed to make single copy of works for private personal purposes provided that such reproduction does not conflict with a normal exploitation of the work and does not unreasonably prejudice the legitimate interests of the author ${ }^{2}$. For example, a

1 Article 11 of Copyright Law of 2001governs non-voluntary licensing and article 17 governs fair use.

2 Art. 17.b. This is in compliance with article 13 of the TRIPs Agreement. In Jordan, fair use defenses are limited to "published" works. It seems that there person may make a single copy of a high-priced book for his private study. Although this example seems self-explanatory it is not the case. It would be left to Jordanian courts to determine to what extent copying a book or recording a broadcast for private use would no longer justified as fair use.

The Law of Ukraine "Copyright and Related Rights" provides for such a concept as reprographic reproduction, i.e. facsimile reproduction in any size (including enlarged or reduced) of the original written or other graphic work or its copy by photocopying or in other similar ways, except for recording in electronic (including digital), optical or other form, which is read by a computer. At the same time, the Law provides for certain restrictions on free copying and computer programs. For example, a person who lawfully possesses a specimen of computer software, without the consent of the author or other person holding the copyright with respect to the software, has the right to manufacture one copy of computer software, provided that the copy is made only for archival purposes or to replace a lawfully acquired specimen in case the original computer software is lost, destroyed or becomes unusable 3 .

Other examples supporting the fair dealing defenses include reproduction of articles published in newspapers or periodicals on current economic, political or religious topics, reproduction for research, illustration for teaching purposes, short extracts for criticism, or review within the limits justified and with proper citation, and library use ${ }^{4}$. Thus, Jordan's Copyright Law of 2001 allows for reproduction in these special cases always provided that the reproduction does not conflict with normal exploitation, does not unreasonably prejudice the interests of the author, and with proper citation. There may be certain factors that courts in Jordan may take into account when judging whether the case in question involves a fair use defense. These factors may include the purpose of the use, the nature of the work used, the amount of quotation or use of the copyrighted work, and the amount of financial gain, if any.

According to the legislation of Ukraine, citation is also possible, and the relevant source must be indicated (the author (s), title of the work,

is a distinction between published and unpublished works for fair use purposes. As such, a biographer or historian may not cite excerpts from an unpublished biography.

${ }^{3}$ Art. 24 of the Law of Ukraine "Copyright and Related Rights" of 1993.

${ }^{4}$ Arts. 17.d, 18? 20 Jordan's Copyright Law of 2001. 
place of publication, year, pages are indicated) However, it should be borne in mind that a quote is a relatively short excerpt from a literary, scientific or any other published work that is used, with mandatory reference to its author and sources of citation, by another person in his work in order to make clearer his statements or to refer to the views of another author in the authentic formulation. It should be noted that Articles 2125 of the Law of Ukraine "On Copyright and Related Rights" provide: a) free use of the work with the author's name; b) free reproduction by libraries and archives of copies of the work in a reprographic manner; c) free reproduction of copies of the work for study; d) free copying, modification and decompilation of computer programs; e) free reproduction of works for personal purposes.

For example, the use of quotations (brief excerpts) form published works to the extent justified by the intended purpose, including quotations from newspaper and magazine articles in the form of press reviews, if this is required by the critical, polemic, scientific or informational nature of the work incorporating the quotations; to freely use quotations in the form of brief excerpts from performances and works incorporated in a phonogram (videogram) or a broadcast program shall be permitted without the consent of the author (or other copyright holder), but with mandatory indication of the author's name and of the source of borrowing

Fair use defense includes presenting or playing a work in a private family gathering. Copyright Law of 2001 does not define what a public or private performance is. One may define public performance as a performance of a work in a place where the public is present and is outside the circle of related family. In other words, if people within the normal circle of a family are present, it is not considered a public performance. However, it is still difficult to determine exactly the number of family members present to qualify as private performance or how many members outside the family must be present vis-à-vis members of the family to qualify as public performance. Courts in Jordan might step in and resolve this issue.

This issue is regulated in more detail in the Law of Ukraine "Copyright and Related Rights", where public performance means presentation of works, performances, phonograms, broadcast organization transmissions by declamation, playing, singing, dancing and other method both directly (live performance) and via any devices or processes (except for air or cable transmission) in places that are or can be attended by persons not belonging to members of a family or close acquaintances of this family, regardless of whether they are present in one place at the same time or in various places at various times.

As mentioned earlier, the other limitation on the exclusive rights of the owner of a work is the non-voluntary (compulsory) license which allows use of works under certain circumstances and conditions without the authorization of the own$\mathrm{er}^{1}$. Article 11 of Copyright Law 2001 sets out a scheme whereby citizens of Jordan can apply under certain conditions to the minister of culture or his assignee for permission to translate foreign works for the purposes of teaching, scholarship and research. Non-voluntary licenses are given in circumstances where translated foreign work was out of stock or if three years have passed since the first publication of the work and no Arabic translation is available. Clearly, the ground for this license is the non-availability of the work. The purpose of this provision could be to ensure transfer and dissemination of knowledge. Another circumstance for granting non-voluntary license is to reproduce and publish a literary, scientific or artistic work where copies of the relevant work have not within the relevant time frame been distributed in Jordan to the general public by the owner of the reproduction right or with his authorization at a price reasonably related to that normally charged in Jordan for comparable works.

However, for any work translated or reproduced via a non-voluntary license by virtue of Copyright Law 2001, fair compensation must be paid in respect of the use. The purpose of nonvoluntary licensing in the Copyright Law of 2001 is the dissemination of copyrighted works to the public where the national legislature might fear that the non-availability of these works could hinder the development of knowledge. It should be noted, however, that the justification for nonvoluntary licenses should not be abused.

\section{E. Copyright Term}

The copyright period required by Copyright Law of 2001 is life of the author and 50 years

1 The Copyright Law of 2001 in article 11 authorizes non-voluntary licenses. Therefore, they are determined specifically in the law and do not result from the discretion of any person including the copyright owner. Article 11 is in line with the Appendix of Berne Convention of 1971 that allows these exceptions for developing countries. Article I of the Appendix limits the application of the Appendix to countries which are regarded as developing in conformity with the established practice of the General Assembly of the U.N. Any developing country member of Berne Convention which wishes to introduce the special compulsory licenses is required to deposit a declaration notification with the Director General of WIPO. 
after his death ${ }^{1}$. However, Jordan may extend this term $^{2}$. For example, the post mortem copyright period can be increased to 70 years. Protection term for cinematographic and television works, any work whose author or right holder is a legal entity, any work published for the first time after the death of its author, and anonymous and pseudonymous works is 50 years from date of publication. Photographic and applied art works are protected for 25 years. Thus, Jordan's Copyright Law does not assimilate applied art and photographic works for example to other literary works but rather provides protection for shorter periods.

The period of protection of performers and producers of phonograms is until the end of 50 years from the end of the year in which the fixation was made or the performance took place $^{3}$. Term of protection of broadcasting organizations is 20 years from the end of the year in which the broadcasting took place.

According to article 28 of the Law of Ukraine "Copyright and Related Rights", copyright to a work shall arise as a result of the fact of its being created and shall start being effective on the day of creation of the work. Copyright shall remain in effect throughout the author's lifetime and for 70 years after his death, except in the cases provided for by law. For example, with respect to works promulgated anonymously or under a pseudonym, the period of validity of copyright shall terminate 70 years after the promulgation of the work. If a pseudonym accepted by an author leaves no doubts as to the author's identity, or if the author of a work, promulgated anonymously or under a pseudonym, is disclosed not later than 70 years after the promulgation of the work, the term stipulated in part two of this Article shall apply.

In addition, if an entire work is published (promulgated) not in its entirety, but in consecutive volumes, parts, issues, series, etc., the period of validity of its copyright shall be stipulated separately with respect to each published (promulgated) portion of the work. The copyright to

1 Art. 30. Term of protection under Jordan's Copyright Law is in line with article 7.1 of the Berne Convention which provides protection for lifetime plus 50 years after death. It is also in compliance with article 12 of the TRIPs Agreement.

2 The period in article 7.1 of the Berne Convention is minimum period and article 7.6 of the convention allows countries of the union to grant longer terms.

${ }^{3}$ Art. 23.d. The TRIPs standard is higher since the period of protection under Rome Convention for the Protection of Performers, Producers of Phonograms and Broadcasting Organizations is only 20 years. works of posthumously rehabilitated authors shall remain in effect for 70 years after their rehabilitation. Copyright to a work that was first published within 30 years after the author's death shall remain in effect for 70 years after the date of the lawful publication thereof.

Any person, who promulgates a nonpromulgated work for the first time after expiration of the term of protection of copyright with respect to the work, shall enjoy protection equal to the protection of the author's proprietary rights. The term of protection of these rights shall be 25 years after the time when the work was first promulgated.

As we can see, the laws of Ukraine and Jordan on copyright have some similarities in terms of the impact of this right. However, Jordan's and Ukraine's Copyright Law granted the minimum period of protection as stipulated under the TRIPs Agreement and did not grant a longer term.

\section{F. Remedies}

The Copyright Law of 2001 expressly deals with the question of available remedies for copyright infringement. Enforcement provisions are to be found in articles 46-52 of the law. These measures could be divided into provisional measures, civil remedies, criminal penalties, and measures taken at the border.

Provisional measures include search and seizure of infringing copies and evidence of infringement on a protective basis in an interlocutory proceeding. These measures have the purpose of preventing infringements from occurring and preserving relevant evidence. In this way, the alleged infringer is prevented from relocating the suspected infringing materials so as to avoid detection. Any provisional measure must be accompanied by adequate collateral so as to prevent misuse of these measures.

Civil remedies compensate the owner of rights for economic injury suffered because of infringement. Criminal sanctions are intended to punish those who commit acts of infringement, theft, or piracy of copyright and related rights and, as in the case of civil remedies, to deter further infringement. The Copyright Law of 2001 does require for purposes of imposing criminal penalties the condition of intention. The purpose of punishment is served by imposing substantial fines and/or sentencing that correspond to the seriousness of the crime particularly in cases of repeat offenses ${ }^{4}$.

${ }^{4}$ Under the current version of the Copyright Law of 2001, criminal penalties are imprisonment for a period between 3 months-3 years and a fine of JD10003000 or one of these two sentences. In case of repetition penalties would be applied to the maximum. 
The final category of remedies is measures to be taken at the borders. Border measures are different from the enforcement measures described above in that they involve actions by customs authorities at the borders rather than by the judicial authorities. Border measures are absent from the Copyright Law of 2001. However, such measures are covered under the Customs Law. The right holder may petition the court, after depositing a cash or bank guarantee and submitting sufficient evidence, to suspend the release of suspected infringing products. In case of suspected infringement on intellectual property rights related to copyright and trademark, the clearance of imported goods can be suspend if there is a prima facie case of infringement.

Finally, it is worth mentioning that Jordan's Copyright Law of 2001 grants the staff, which is limited in number and finance, of the Copyright Protection Office within the National Library Department the status of judicial police ${ }^{1}$. As such, they have the right search and seizure. In other words, staff could search premises without the need for warranty or being accompanied by police officers. The police powers of the staff have increased. Any staff may search, stop, and board a vehicle suspected of having in its possession goods which violate Copyright Law.

Section V of the Law of Ukraine "Copyright and Related Rights" is devoted to the protection of these rights. In general, the protection of personal non-proprietary and proprietary rights of copyright and (or) related rights holders shall be effected in compliance with the procedure prescribed by administrative, civil and criminal legislation. The Law on the Termination of Copyright and/or Related Rights with the Use of the Internet, as well as the obligations of hosting service providers to ensure the protection of copyright and (or) related rights with the use of the Internet, should be considered quite progressive. At the same time, the problem of copyright and related rights protection on the Internet is of increasing interest nowadays, as no unambiguous and unified position for all states has been developed so far. The solution to the problems of pro- tection of intellectual property on the Internet should be, first, specialized legislation in the state. Then authors would not be afraid of such negative phenomena as plagiarism, piracy, and electronic libraries could work properly without compromising anyone's rights. In this case, users will be able to find the information they need in a way convenient for them and without violating the law, and the authors will have no concern for their copyright. Copyright infringement may be related to the infringement of his or her personal non-proprietary or proprietary copyright.

\section{G. Retroactivity}

Article 54 of the Copyright Law of 2001 is concerned with retroactivity. It is to apply to all works which at the moment the Law came into force existed, but will not apply retroactively with respect to infringements that occurred before that date. In other words, the Law would apply to works that have existed and not yet fallen into the public domain through the expiry of the term of protection. This article needs some clarification to determine its scope.

\section{Conclusions}

Legal relations, which are subject to legal regulation and protection in the field of copyright, are regulated and subject to the protection of various branches of law. In particular, legal relations in the field of copyright arise as a subject of protection in the field of civil, administrative, criminal law as derived from copyright, because they arise from liability for those violations that are formed, developed and terminated in connection with copyright. This diversity of copyright protection is due to the fact that the threat of harm to copyright must be neutralized by legal means and methods (the main condition - they must be legal).

Offenses against copyright relations significantly violate the order of relations between the subjects of copyright (individuals, society, state), which leads to negative consequences in the form of a threat of harm to the interests (or their occurrence) of both subjects.

\section{List of References}

1. Kovalenko I. A. Actual problems of protection and defence of intellectual property rights in the internet in the conditions of globalization of society and modern technologies. Scientific Notes of Taurida National V. I. Vernadsky University. Series: Legal Sciences. 2018. Vol. 29 (68), No. 3. Pp. 52-55.

Came to the Editorial Board 19 August 2020

\footnotetext{
${ }^{1}$ Provisional Copyright Law No. 52 of 2001, supra note 5, art. 36.
} 


\section{МАЛКАВІ Б., АБЛАМСЬКИЙ С. Є. НОРМИ АВТОРСЬКИХ ПРАВ, ПОРУШЕННЯ АВТОРСЬКИХ ПРАВ І ЗАСОБИ ЗАХИСТУ В УКРАЇНІ ТА ЙОРДАНІЇ: ЯКІ ЦІКАВІ ТРУДНОЩІ ІСНУЮТЬ У ДВОХ ЮРИСДИКЦІЯХ?}

Питання захисту авторських прав стали чудовою ініціативою, яка завойовує схвальні світові позиції у сфері законодавства про інтелектуальну власність, оскільки спрямована на захист ідей автора, щоб їх не порушила та не узурпувала інша особа без його згоди чи дозволу. Було ухвалено безліч міжнародних, регіональних і навіть національних правових норм, які гарантують захист авторських прав від порушень. У відповідь на такі тенденції Україна та Йорданія підписали і дотримуються правових норм щодо захисту авторських прав. Незважаючи на те, що названі країни запроваджують увесь спектр засобів захисту, певний аспект порушень все ще залишається, що порушує раціональність закону, оскільки він спрямований на забезпечення захисту авторських прав. Метою нашої статті $\epsilon$ вивчення наслідків порушення авторських прав. Зрозуміло, що аспект порушення авторських прав зачіпає права, якими володіє автор у питаннях, пов'язаних із захистом авторських прав в Україні та Йорданії. Відповідаючи на фундаментальне запитання щодо аспекта порушення авторських прав в обох країнах, порівняльне дослідження було визнано необхідним для вивчення того, чи мають обидві країни однакові труднощі внаслідок порушення авторських прав. Зроблено висновок, що проблема порушення авторських прав є загальною проблемою, хоча обидві країни мають надійне законодавство, тому зазначено, що дослідження такого масштабу $є$ необхідним для забезпечення й гарантування захисту авторських прав.

Ключові слова: авторське право, автор, правові норми, порушення авторських прав.

\section{МАЛКАВИ Б., АБЛАМСКИЙ С. Е. НОРМЫ АВТОРСКИХ ПРАВ, НАРУШЕНИЕ АВТОРСКИХ ПРАВ И СРЕДСТВА ЗАЩИТЫ В УКРАИНЕ И ИОРДАНИИ: КАКИЕ ИНТЕРЕСНЫЕ СЛОЖНОСТИ СУЩЕСТВУЮТ В ДВУХ ЮРИСДИКЦИЯХ?}

Вопросы защиты авторских прав стали замечательной инициативой, которая завоевывает положительные мировые позиции в сфере законодательства об интеллектуальной собственности, поскольку направлена на защиту идей автора, чтобы их не нарушило и не узурпировало другое лицо без его согласия или разрешения. Было принято множество международных, региональных и даже национальных правовых норм, гарантирующих защиту авторских прав от нарушений. В ответ на такие тенденции Украина и Иордания подписали и соблюдают правовые нормы по защите авторских прав. Несмотря на то, что названные страны вводят весь спектр средств защиты, определенный аспект нарушений все еще остается, что нарушает рациональность закона, поскольку он направлен на обеспечение защиты авторских прав. Целью нашей статьи является изучение последствий нарушения авторских прав. Понятно, что аспект нарушения авторских прав затрагивает права, которыми обладает автор в вопросах, связанных с защитой авторских прав в Украине и Иордании. Отвечая на фундаментальный вопрос об аспекте нарушения авторских прав в обеих странах, сравнительное исследование было признано необходимым для изучения того, имеют ли обе страны одинаковые трудности вследствие нарушения авторских прав. Сделан вывод, что проблема нарушения авторских прав является общей проблемой, хотя обе страны имеют надежное законодательство, потому указано, что исследования такого масштаба необходимо для обеспечения и гарантирования защиты авторских прав.

Ключевые слова: авторское право, автор, правовые нормы, нарушение авторских прав. 